\title{
Interaksi Pembelajaran Pendidikan Agama Islam pada Peserta Didik Berkebutuhan Khusus di Sekolah Dasar Negeri 30 Palembang
}

\author{
Yulianti $^{1^{*}}$, Dian Erlina ${ }^{2}$ \\ ${ }^{1 *}$ Universitas Islam Negeri Raden Fatah, Palembang, Indonesia \\ yuliantidulbakri@gmail.com \\ ${ }^{3}$ Universitas Islam Negeri Raden Fatah, Palembang, Indonesia \\ dianerlina uin@radenfatah.ac.id
}

\begin{abstract}
Learning interaction is a reciprocal relationship between students and educators, between students, students with learning resources, and students with the learning environment in teaching and learning activities to achieve goals. In learning interactions also occur social interaction and communication. The purpose of this study, first, is to analyze the interaction of learning of autistic students in Islamic Religious Education subjects at Sekolah Dasar Negeri 30 Palembang, including; learning interactions between Islamic Religious Education teachers and autistic students, and learning interactions between students in general and autistic students. secondly, to analyze the constraints of the learning interactions of autistic students in Islamic Religious Education subjects at Sekolah Dasar Negeri 30 Palembang. The approach used in this research is a qualitative approach, and the type of research used in this study is a case study, data collection techniques, namely observation, interviews, and documentation. Data analysis techniques in this study used the Miles and Huberman model, namely data reduction, data presentation, and drawing conclusions.
\end{abstract}

Keywords : Learning Interactions, Inclusive Education, Autistic Children.

\section{INFORMASI ARTIKEL}

Submitted, August 12, 2019

Revised, October 15, 2019

Accepted, December 14, 2019 


\section{PENDAHULUAN}

Pendidikan pada dasarnya adalah hak semua orang tanpa terkecuali, baik pria maupun wanita, baik anak normal maupun anak berkebutuhan khusus. Anak berkebutuhan khusus menurut Hallahan dan Kauffman adalah anak-anak yang mempunyai perbedaan yang sangat mencolok dari anak-anak pada umumnya dalam satu hal atau lebih meliputi mentally retarded, gifted, learning disabled, emotionally disturb, physically handicapped. Menurut Kirk dan Gallagher, anak berkebutuhan khusus adalah anak yang berbeda dari anak rata-rata atau normal dalam perihal; karakteristik mental, kemampuan sensori, kemampuan komunikasi, perilaku sosial serta karakteristik fisik. Selanjutnya menurut Suran dan Rizzo, anak berkebutuhan khusus adalah anak yang secara signifikan berbeda dalam beberapa dimensi yang penting dari fungsi kemanusiaannya. Artinya mereka secara fisik, psikologis, kognitif atau sosial terhambat dalam mencapai tujuan-tujuan dan potensinya secara maksimal, meliputi mereka yang tuli, buta, mempunyai gangguan bicara, cacat tubuh, retardasi mental, gangguan emosional. Begitu pula dengan anak-anak yang berbakat dengan intelegensi yang tinggi (Aziz, 2015).

Berbicara pendidikan inklusif adalah berbicara semua anak. Anak adalah sebagai pribadi yang unik, sebagai pribadi unik mereka memiliki perbedaan, perlu tumbuh kembang dalam keluarga, sekolah dan masyarakat. untuk mengakomodasi keberagaman karakteristik anak, maka perlu adanya sistem pendekatan atau layanan pendidikan. Pendidikan inklusif adalah sebuah konsep atau pendekatan pendidikan yang berusaha menjangkau semua individu tanpa kecuali atau dengan kata lain pendidikan inklusif adalah sistem pendidikan yang terbuka bagi semua individu serta mengakomodasi semua kebutuhan sesuai dengan kondisi masing-masing individu. Pendidikan inklusif adalah pendidikan yang menghargai perbedaan peserta didik dan memberikan layanan kepada setiap peserta didik sesuai dengan kebutuhannya. Pendidikan inklusif adalah pendidikan yang tidak diskriminatif. Pendidikan yang memberikan layanan terhadap semua peserta didik tanpa memandang kondisi fisik, mental, intelektual, sosial, emosi, dan sebagainya (Kustawan, 2016).

Pendidikan untuk anak berkebutuhan khusus, yang selama ini mereka hanya di Sekolah Luar Biasa (SLB) yang secara tidak disadari sistem pendidikan SLB telah membangun tembok bagi peserta didik berkebutuhan khusus telah menghambat proses saling mengenal antara peserta didik difabel dengan peserta didik non-difabel. Dengan keterlibatan di pendidikan regular (sekolah pada umumnya) dengan penyatuan (inclusion) maka membangun kembali mental psikologi bagi peserta didik berkebutuhan khusus, atau program inklusi, yaitu pendidikan yang memberikan kesempatan yang sama kepada semua peserta didik termasuk yang berkebutuhan khusus untuk mendapatkan pendidikan di kelas reguler tanpa pembedaan (Rohmadi, 2012).

Pentingnya penyelenggaraan pendidikan inklusif di sekolah umum/kejuruan banyak manfaatnya bagi peserta didik berkebutuhan khusus adalah mereka memiliki rasa percaya diri dan memiliki kesempatan menyesuaikan diri serta memiliki kesiapan dalam menghadapi kehidupan yang nyata pada lingkungan pada umumnya. Manfaat pendidikan inklusif bagi peserta didik pada umumnya adalah peserta didik dapat belajar mengenai keterbatasan dan kelebihan tertentu pada teman-temannya. Manfaat pendidikan inklusif bagi guru adalah guru akan lebih tertantang untuk mengajar lebih baik dan dapat mengakomodasi semua peserta didik sehingga akan berupaya untuk meningkatkan wawasannya mengenai keberagaman karakteristik semua peserta didik. Manfaat pendidikan inklusif bagi orang tua adalah orang tua merasa dihargai atau dapat meningkatkan penghargaan terhadap peserta didik. Manfaat pendidikan inklusif bagi pemerintah dan pemerintah daerah adalah kebijakan pendidikan terlaksana berlandaskan pada azas demokrasi, berkeadilan dan tanpa diskriminasi (Kustawan, 2016). 
Belajar mengajar atau disebut juga pembelajaran adalah suatu kegiatan pendidikan yang mewarnai interaksi yang terjadi antara guru dengan anak didik. interaksi ini dilakukan, diarahkan untuk mencapai tujuan tertentu yang telah dirumuskan sebelum kegiatan dilakukan. Dalam interaksi ini guru dengan sadar merencanakan kegiatan mengajarnya secara sistematis dengan memanfaatkan segala sumber daya yang ada. Di antara hal yang harus dipenuhi oleh guru adalah bahan pelajaran yang disampaikan guru dapat dikuasai oleh anak didik secara tuntas. Ini memang hal yang sangat sulit yang dirasakan oleh guru. Kesulitan itu karena sosok anak didik bukan hanya individu dengan segala keunikannya, tetapi juga makhluk sosial dengan latarbelakang yang berlainan (Sukardi, 2013).

Menurut Makmun sebagaimana yang dikutip oleh Mukhtar dan Iskandar, proses belajar mengajar merupakan suatu rangkaian interaksi antara siswa dengan guru dalam rangka mencapai tujuannya. Maknanya terjadi perilaku belajar pada siswa dan perilaku mengajar pada pihak guru yang terjadi hubungan interaktif yang bersifat mengikat antara aktivitas kedua belah pihak (Mukhtar \& Iskandar, 2010).

Peserta didik autis yang merupakan salah satu bagian dari anak berkebutuhan khusus. Autis merupakan sebuah kondisi yang dialami oleh seseorang semenjak lahir ataupun muncul saat usia dibawah lima tahun yang menjadikan diri anak tersebut tidak mampu membentuk hubungan sosial dan berkomunikasi secara normal. Anak autis mengalami gangguan komunikasi, gangguan interaksi sosial dan gangguan perilaku (Aziz, 2015). Dengan kondisi seperti ini maka interaksi pembelajaran pada peserta didik berkebutuhan khusus autis akan mengalami kesulitan atau hambatan. Hambatan pembelajaran pada anak autis umumnya mengalami hambatan komunikasi, baik itu komunikasi verbal maupun nonverbal, dan hambatan dalam interaksi sosial.

\section{METODOLOGI PENELITIAN}

Pendekatan yang digunakan dalam penelitian ini adalah pendekatan kualitatif, penelitian kualitatif merupakan metode-metode untuk mengeksplorasi dan memahami makna sejumlah individu atau sekelompok orang yang berasal dari masalah sosial atau kemanusiaan (Creswell, 2016). Adapun jenis penelitian yang digunakan dalam penelitian ini adalah studi kasus. Studi kasus merupakan rancangan penelitian yang ditemukan di banyak bidang, khususnya evaluasi, di mana peneliti mengembangkan analisis mendalam atas suatu kasus, sering kali program, peristiwa, aktivitas, proses, atau satu individu atau lebih (Creswell, 2016).

Untuk mengumpulkan data yang dibutuhkan dalam penelitian ini, peneliti menggunakan teknik pengumpulan data, yaitu observasi kualitatif, wawancara kualitatif dan dokumen kualitatif. Observasi kualitatif (qualitative observation) adalah ketika peneliti langsung ke lapangan untuk mengamati perilaku dan aktivitas individu-individu di lokasi penelitian, peneliti mencatat, baik dengan cara terstruktur maupun semistruktur (misalnya, dengan mengajukan sejumlah pertanyaan yang memang ingin diketahui oleh peneliti) dan aktivitas-aktivitas di lokasi penelitian. Wawancara kualitatif (qualitative interview) adalah peneliti dapat melakukan face to face interview (wawancara berhadap-hadapan) dengan partisipan. Dokumen kualitatif ini bisa berupa dokumen public, misalnya laporan kantor (Creswell, 2016).

Teknik analisis data dalam penelitian ini menggunakan model Miles and Huberman, yaitu reduksi data, penyajian data, dan penarikan kesimpulan. Mereduksi data berarti merangkum, memilih hal-hal yang pokok, memfokuskan pada hal-hal yang penting, dicari tema dan polanya dan membuang yang tidak perlu. Penyajian data dalam penelitian kualitatif adalah dengan teks yang bersifat naratif. Data Display (Penyajian Data) dalam penelitian ini, peneliti akan mulai menganalis dari data yang telah dikumpulkan, dengan menggunakan triangulasi teknik (peneliti menggunakan teknik pengumpulan data yang berbeda-beda untuk mendapatkan 
data dari sumber yang sama). Conclusion Drawing adalah penarikan kesimpulan (Sugiyono, 2010).

\section{HASIL DAN PEMBAHASAN}

Berdasarkan temuan hasil penelitian dan pembahasan melalui proses observasi, wawancara dan dokumentasi, peneliti menganalisis Interaksi pembelajaran terhadap peserta didik autis pada mata pelajaran Pendidikan Agama Islam di Sekolah Dasar Negeri 30 Palembang, yang meliputi analisis interaksi pembelajaran antara guru Pendidikan Agama Islam dengan peserta didik autis, dan analisis interaksi pembelajaran peserta didik pada umumnya dengan peserta didik autis.

\section{Interaksi Pembelajaran Antara Guru PAI Dengan Peserta Didik Autis}

Dalam proses interaksi antara guru dan siswa dibutuhkan komponen-komponen. Komponen-komponen interaksi pembelajaran adalah sebagai berikut : 1) Tujuan, tujuan merupakan hal yang pertama kali harus dirumuskan dalam kegiatan interaksi edukatif, sebab tujuan dapat memberikan arah yang jelas dan pasti kemana kegiatan pembelajaran dibawa oleh guru. Dengan berpedoman pada tujuan guru dapat menyeleksi tindakan mana yang harus dilakukan dan tindakan mana yang harus ditinggalkan. 2) Bahan Pelajaran, bahan pelajaran adalah unsur inti dalam kegiatan interaksi edukatif, sebab tanpa bahan pelajaran proses interaksi edukatif tidak akan berjalan. Dalam pemilihan bahan pelajaran harus disesuaikan dengan kondisi tingkatan murid yang akan menerima pelajaran. Selain itu bahan pelajaran mutlak harus dikuasai guru dengan baik. 3) Metode, metode adalah suatu cara yang dipergunakan untuk mencapai tujuan yang telah ditetapkan, karakteristik metode yang memiliki kelebihan dan kelemahan maka guru menggunakan metode yang bervariasi. 4) Kegiatan Belajar Mengajar, kegiatan belajar mengajar adalah inti dari kegiatan dalam pendidikan segala sesuatu yang telah diprogramkan akan dilaksanakan dalam kegiatan belajar mengajar, dalam pengelolaan dan pengajaran kelas yang perlu diperhatikan oleh guru adalah perbedaan anak didik pada aspek biologis, intelektual dan psikologis. Interaksi pembelajaran yang akan terjadi juga akan dipengaruhi oleh cara guru memahami perbedaan individual anak didik. 5) Alat, alat adalah segala sesuatu yang dapat digunakan dalam rangka mencapai tujuan pembelajaran. Alat nonmaterial dan alat material biasanya dipergunakan dalam kekuatan interaksi edukatif. Alat nonmaterial berupa suruhan, perintah, larangan dan nasehat. Alat material berupa globe, papan tulis, gambar, video, dan lain-lain. 6) Sumber, sumber belajar dapat diperoleh di sekolah, di halaman, di pusat kota, di pedesaan dan sebagainya. Pemanfaatan sumber pengajaran tergantung pada kreativitas guru, waktu, biaya, dan kebijakan-kebijakan lainnya. 7) Evaluasi, evaluasi adalah suatu kegiatan yang dilakukan untuk mendapatkan data tentang sejauh mana keberhasilan anak didik dalam belajar dan keberhasilan guru dalam mengajar. Pelaksanaan evaluasi dilakukan oleh guru dengan memakai seperangkat instrumen pengali data seperti tes perbuatan, tes tertulis, tes lisan (Djamarah, 2000).

Interaksi pembelajaran antara Guru Pendidikan Agama Islam dengan peserta didik autis adalah sebagai berikut :

\section{Guru PAI Memiliki Tujuan Pembelajaran}

Tujuan pembelajaran peserta didik autis sama dengan tujuan pembelajaran peserta didik pada umumnya, perumusan tujuan pembelajaran tidak ada perbedaan antara peserta didik autis dengan peserta didik pada umumnya dalam RPP yang dibuat guru PAI. Berdasarkan hasil dokumentasi, Rencana Pelaksanaan Pembelajaran (RPP) guru PAI WH untuk kelas 3 yang masih menggunakan kurikulum KTSP. memiliki tujuan pembelajaran yaitu siswa dapat menjelaskan pengertian sifat wajib bagi Allah SWT dan dapat menyebutkan lima sifat wajib 
bagi Allah SWT dengan benar. Kemampuan yang harus dimiliki peserta didik autis tidak dibedakan dengan kemampuan peserta didik pada umumnya.

\section{Guru PAI Memiliki Bahan Pelajaran}

Bahan pelajaran atau materi pelajaran yang dipilih guru PAI adalah Materi pembelajaran yaitu pengertian sifat wajib bagi Allah SWT, sifat wajib Allah ada 20. Lima diantaranya ialah wujud (ada), qidam (terdahulu), baqa (kekal), mukhalafatu lilhawadis (berbeda dengan makhluk), qiyamuhu binafsihi (berdiri sendiri). Bahan pelajaran atau materi pelajaran untuk peserta didik autis yang sama juga dengan peserta didik pada umumnya. Tidak ada perbedaan dalam pemberian materi pelajaran oleh guru PAI baik peserta didik autis maupun peserta didik pada umumnya. Guru PAI menguasai bahan pelajaran dengan baik.

\section{Guru PAI Menggunakan Metode}

Metode pembelajaran untuk peserta didik autis yang sama dengan peserta didik pada umumnya. Metode pembelajaran yang digunakan guru PAI yaitu metode ceramah, tanya jawab, dan latihan tentang definisi sifat wajib bagi Allah SWT dan menyebutkan lima sifat wajib bagi Allah SWT. Metode pembelajaran secara umum tidak dibedakan antara peserta didik pada umumnya maupun peserta didik autis, akan tetapi siswa yang memiliki kebutuhan khusus diberikan strategi pembelajaran yang khusus yaitu guru PAI tidak pernah melakukan kontak mata secara langsung pada peserta didik autis, dan tidak pernah memaksa peserta didik autis untuk melihat guru PAI.

\section{Kegiatan Belajar (Peserta Didik) Mengajar (Guru PAI)}

Secara umum kegiatan pembelajaran meliputi kegiatan pendahuluan, kegiatan inti dan kegiatan penutup. Adapun langkah-langkah kegiatan pembelajaran tersebut antaralain : Kegiatan Pendahuluan ; Apersepsi dan Motivasi : Memberikan cerita singkat dan menarik yang berkaitan dengan bahan ajar (melalui sepenggal kisah). Mengajukan beberapa pertanyaan tentang siapa Allah SWT. Memberi pendahuluan menggunakan fitur mutiara Islam tentang bahan ajar yang akan disampaikan. Kegiatan Inti ; Eksplorasi, dalam kegiatan eksplorasi, guru menyuruh siswa mendengarkan dan mengamati uraian guru tentang bahan ajar yang disajikan. Siswa menyampaikan pendapat tentang definisi sifat wajib bagi Allah SWT. Elaborasi, dalam kegiatan elaborasi, guru menyuruh siswa menyebutkan lima sifat wajib bagi Allah SWT secara klasikal, kelompok dan individu. Konfirmasi, dalam kegiatan konfirmasi, guru bertanya jawab tentang hal-hal yang belum diketahui siswa. Guru bersama siswa bertanya jawab meluruskan kesalahan pemahaman, memberikan penguatan dan penyimpulan. Kegiatan Penutup ; dalam kegiatan penutup, guru menyuruh siswa untuk menyimpulkan kisah dalam sepenggal kisah yang telah dibacakan menggunakan bahasa sendiri. Guru mendengarkan siswa mengulang penyebutan sifat wajib bagi Allah SWT secara berkelompok.

\section{Guru PAI Menggunakan Alat}

Guru PAI menggunakan alat pembelajaran yaitu tulisan lima sifat wajib bagi Allah di papan tulis. Peserta didik autis maupun peserta didik pada umumnya semua dapat melihat tulisan guru PAI di papan tulis. Tidak ada alat khusus yang disediakan guru PAI dalam interaksi pembelajaran untuk peserta didik autis.

\section{Guru PAI Menggunakan Sumber}

Sumber belajar yang digunakan guru PAI adalah buku Pendidikan Agama Islam kelas 3, pengalaman guru dan lingkungan sekitar. Sebelum interaksi pembelajaran dimulai guru PAI membagikan buku Pendidikan Agama Islam kelas 3, satu buku untuk satu meja atau satu buku untuk dua peserta didik. Disini peserta didik pada umumnya dapat belajar bersama dengan 
peserta didik autis dengan menggunakan satu buku untuk belajar bersama teman sebangku. Buku Pendidikan Agama Islam tersebut akan diambil kembali oleh guru PAI setelah jam pelajaran selesai.

\section{Guru PAI Menggunakan Evaluasi}

Guru PAI dalam melakukan kegiatan evaluasi atau penilaian, bila peserta didik pada umumnya dapat menjawab soal dari satu sampai sepuluh, maka peserta didik berkebutuhan khusus hanya cukup menjawab soal dari satu sampai lima saja. Perbedaan penilaian yang dilakukan guru PAI karena memperhatikan kondisi peserta didik berkebutuhan khusus. Ada perbedaan penilaian untuk peserta didik autis dengan peserta didik pada umumnya. Evaluasi atau penilaian guru PAI bersifat individual.

\section{Pola Komunikasi Guru PAI}

Pola komunikasi dalam interaksi pembelajaran antara guru PAI dengan peserta didik autis, yaitu komunikasi satu arah. Dalam komunikasi ini guru PAI berperan sebagai pemberi aksi dan peserta didik autis sebagai penerima aksi (pendidik aktif, peserta didik pasif). Saat guru PAI menjelaskan materi pelajaran peserta didik autis memperhatikan penjelasan guru PAI atau peserta didik autis dapat fokus belajar dan ada juga peserta didik autis yang lain tidak fokus belajar asyik pada mainannya sendiri. Peserta didik autis tidak pernah bertanya pada guru PAI, namun bila guru PAI bertanya kepada peserta didik autis baru akan menjawab pertanyaan dari guru PAI tersebut dan ada juga peserta didik autis yang hanya diam bila ditanya guru PAI. Komunikasi verbal yang digunakan guru PAI yaitu bahasa yang sederhana dan jelas, serta menuliskan di papan tulis. Selain itu, guru PAI juga menggunakan komunikasi nonverbal, yaitu vokalik, cara berbicara atau nada suara. Guru PAI mempunyai nada suara lemah atau volume suara guru PAI terlalu kecil, kinesics, gerakan tubuh, tangan, kaki, dan perilaku mata. Guru PAI menggunakan gerakan tubuh saat interaksi pembelajaran. Haptics atau sentuhan dengan berjabat tangan, guru PAI dengan peserta didik pada umumnya dan peserta didik autis akan berjabat tangan setelah jam pelajaran berakhir. proxemics atau jarak peserta didik autis duduk dekat meja guru, dan peserta didik autis duduk sebangku dengan peserta didik pada umumnya atau duduk sebangku dengan pendamping (shadow).

Peserta didik autis pada kelas 3.A. dalam interaksi pembelajaran, bernama FMP yang terlahir pada tanggal 08 Februari 2010, ia temasuk kelompok yang pasif, dapat menerima pendekatan sosial dan bermain dengan anak lain. FMP duduk sebangku dengan peserta didik pada umumnya, duduk di bangku urutan ke-3 dari bangku guru, ia termasuk siswa yang cerdas, sudah dapat menulis dan membaca. Dalam berkomunikasi sudah berkembang dengan baik, dapat merespon saat namanya dipanggil guru, dan ia dapat menjawab pertanyaan dari guru. Saat guru PAI menjelaskan materi pelajaran, FMP fokus belajar atau ia dapat menyimak dengan baik informasi/penjelasan guru dan ia dapat mengerjakan tugas/latihan sesuai arahan guru. FMP jarak sekali atau tidak pernah bertanya dengan guru PAI. FMP menghindari kontak mata dengan guru PAI.

Peserta didik autis lainnya adalah MRI terlahir pada tanggal 18 Juli 2011. Duduk di bangku paling depan dekat meja guru. Berdasarkan pengamatan peneliti, MRI di dalam kelas duduk sebangku/ditemani dengan shadow (pendambing) yang tak lain adalah mamanya sendiri bernama YT. MRI belum bisa menulis dengan baik, kalau menulis tangannya masih dipegang/dibantu shadow. MRI juga belum bisa membaca. Menurut mamanya, MRI berkesulitan dalam berkomunikasi, walaupun ia bisa berbicara tapi dalam berbicara ia mengalami kesulitan merangkai kata sehingga ia lebih banyak diam. Dalam interaksi sosial MRI termasuk kelompok yang menyendiri. Dalam perilaku bila ia merasa tertekan, ia bangkit dari tempat duduk dan berdiri di depan kelas sambil memutar-mutarkan tubuhnya, sedangkan 
teman sekelasnya tidak ada yang tertawa melihat perilaku MRI tersebut. Saat guru PAI menjelaskan materi pelajaran, ia melihatnya dari sudut matanya, tangannya asyik memegang mainannya, walaupun mamanya memperingatkan dia untuk fokus pada pelajaran. MRI tidak merespon ketika namanya dipanggil guru, dan bila ditanya guru hanya diam saja. MRI jarak sekali atau tidak pernah bertanya dengan guru PAI. MRI melihat dari sudut matanya dengan guru PAI. MRI mengalami kesulitan menulis dan membaca.

\section{Interaksi Pembelajaran Antara Peserta Didik pada Umumnya dengan Peserta Didik Autis}

Anak autis tidak tertarik berinteraksi secara sosial dan mereka kurang tertarik dengan orang lain. Mereka bisa terlibat menyendiri dan tidak peduli dengan orang asing, meskipun mereka bisa merespon orang yang mereka kenal. Mereka mungkin menolak didekati oleh orang lain dan mencoba mengisolasi diri mereka. Ada beberapa tingkat gangguan sosial. Gangguan sosial terletak dalam sebuah spektrum dari seorang yang menyendiri dan menarik diri, sampai pada seseorang yang akan merespons secara pasif jika didekati orang lain, tetapi tidak akan memulai interaksi. Pada ujung spektrum ini, anak berkeinginan mencari perhatian orang lain, tetapi sering tidak tahu cara mengungkapkannya. Anak autis sering memiliki batasan dalam ekspresi bahasa. Umumnya, mereka tidak memahami fungsi bahasa sebagai alat komunikasi dua arah. Meraka akan memahami bahasa secara sederhana dan jelas. Mereka mungkin mengulangi kata yang mereka dengar (echolalia) dan lemah dalam pemahaman bahasa. Walaupun kemampuan bicara mereka mungkin berkembang, mereka bisa menggunakan bahasa untuk berkomunikasi. Sejauh mana anak mempunyai kesulitan komunikasi dapat diletakkan pada sebuah spektrum dari yang tidak berbicara sama sekali sampai yang bisa berbicara cukup baik. Namun lemahnya komunikasi tetap menjadi masalah mendasar pada semua anak autis. Banyak anak autis tidak mengerti ekspresi wajah, gerakan tangan, dan bahasa tubuh. Anak autis mereka mungkin mengalami kesulitan memahami tanda-tanda nonverbal sehingga mereka tidak bisa mengenalnya sebagai petunjuk yang memiliki makna tertentu. Anak autis sering kali membentuk pola perilaku yang kaku. Mereka mungkin mengulang beberapa perilaku, seperti menjatuhkan benda dari meja berulang kali atau memutar koin. Mereka bisa mengembangkan obsesi terhadap benda favorit atau terobsesi dengan mobil, kereta api, atau sepeda motor, dan lain-lain. Mengubah rutinitas biasa bisa menyebabkan tekanan dan mereka bisa menolak untuk berubah. Mereka kesulitan dengan permainan imajinatif. Mereka sering lamban dalam permainan pura-pura atau tidak ikut sama sekali, dan mereka sulit membedakan antara kenyataan dan imajinasi. Mereka juga kurang kreatif (Glazzard, et al, 2016). Teman, dalam keseharian di sekolah anak autis memerlukan teman untuk mengembangkan kemampuan melakukan interaksi sosial di sekolah. Peran teman dalam komunitas belajar anak autis dapat difungsikan sebagai media untuk melatih siswa berkomunikasi, melakukan interaksi sosial, mengembangkan kemampuan sensori anak dan memperbaiki sikap atau perilaku anak (Koswara, 2016)

Secara fisik peserta didik autis sama dengan peserta didik pada umumnya, yang membedakannya cara mereka berinteraksi, komunikasi, dan perilaku. Di Sekolah Dasar Negeri 30 Palembang peserta didik autis belajar bersama di kelas reguler dengan peserta didik pada umumnya. interaksi peserta didik pada umumnya dengan peserta didik autis, antara lain :

\section{Komunikasi}

Peserta didik autis lebih banyak diam dan sibuk dengan dirinya sendiri, tidak ada inisiatif untuk berkomunikasi dengan peserta didik pada umumnya. Komunikasi selalu dimulai oleh peserta didik pada umumnya. Peserta didik pada umumnya dapat berfungsi sebagai teman untuk melatih peserta didik autis berkomunikasi. 


\section{Interaksi Sosial}

Peserta didik autis dalam interaksi sosial ada yang senang menyendiri, dimana lebih banyak menghabiskan waktunya sendiri daripada dengan peserta didik pada umumnya, tampak sangat pendiam, serta tidak dapat merespon bila diajak berbicara dan sangat enggan untuk berinteraksi dengan teman sebaya atau peserta didik pada umumnya. Peserta didik autis yang pasif masih mudah diajak berinteraksi oleh peserta didik pada umumnya, dapat berbicara dengan baik walau interaksi selalu dimulai oleh peserta didik pada umumnya. Peserta didik pada umumnya melakukan interaksi sosial dengan belajar atau bermain dengan peserta didik autis.

\section{Perilaku}

Peserta didik autis tidak merespon ketika dipanggil atau seperti tidak mendengar ketika ada orang yang berbicara padanya. Namun ada juga peserta didik autis yang dapat merespon ketika dipanggil dan mendengar ketika ada orang atau peserta didik pada umumnya yang berbicara padanya. Peserta didik autis bila merasa tertekan akan melakukan gerakan tubuh yang tidak biasa seperti memutar-mutarkan tubuhnya. Peserta didik autis obsesi terhadap benda favorit, sehingga benda atau mainan favoritnya juga dibawa ke sekolah.

Secara tidak langsung peserta didik pada umumnya dapat membantu peserta didik autis dalam interaksi sosial maupun komunikasi. Bila peserta didik autis yang mengalami gangguan interaksi sosial, maka peserta didik pada umumnya dapat membantunya dengan cara bermain bersama atau belajar bersama, sehingga peserta didik autis yang suka menyendiri beransuransur mulai dapat membuka diri menerima kehadiran peserta didik lainnya. Dalam interaksi pembelajaran selalu memerlukan komunikasi, sedangkan peserta didik autis yang mengalami gangguan komunikasi, secara tidak langsung peserta didik pada umumnya membantu peserta didik autis dalam berkomunikasi baik verbal maupun non verbal

\section{Kendala Interaksi Pembelajaran Terhadap Peserta Didik Autis Pada Mata Pelajaran Pendidikan Agama Islam di Sekolah Dasar Negeri 30 Palembang}

Dalam interaksi pembelajaran dipengaruhi oleh banyak faktor, baik faktor internal maupun faktor eksternal. Faktor-faktor tersebut adalah sebagai berikut :

\section{Faktor Internal}

Faktor internal adalah faktor-faktor yang berasal dari dalam individu, yaitu kondisi/keadaan jasmani dan rohani siswa (Sukardi, 2013). Kendala interaksi pembelajaran terhadap peserta didik autis adalah 1) Ada peserta didik autis yang mengalami kesulitan berbicara dan bahasa, dan ada juga peserta didik autis yang memiliki kemampuan bicara dan bahasa yang sudah berkambang baik. Kesulitan komunikasi anak autis dapat terjadi karena pemahaman informasi dan ketidakmampuan menyampaikan keinginan atau maksud sehingga peserta didik autis tidak bisa menjawab pertanyaan guru atau tidak bisa menjawab pertanyaan peserta didik pada umumnya. 2) Ada peserta didik autis yang menyendiri, tidak mau belajar atau bermain bersama teman yang lain, dan ada juga yang pasif, dapat belajar atau bermain bersama. Kesulitan interaksi sosial anak autis dapat terjadi karena tidak bisa bermain atau belajar bersama peserta didik pada umumnya. 3) Ada peserta didik autis dalam prestasi akademik rendah, karena ia mengalami kesulitan belajar (belum bisa menulis dan membaca). Kesulitan belajar anak autis dapat terjadi karena belum bisa membaca dan menulis, maka ia kesulitan dalam mengerjakan tugas-tugas yang diberikan oleh guru PAI atau kesulit mengerjakan soal-soal pada saat evaluasi karena ia belum bisa menulis dan membaca. Kesulitan 
belajar anak autis juga dapat terjadi karena ia tidak fokus, melihat dan mendengar pada saat penjelasan/informasi yang disampaikan guru PAI, sehingga peserta didik autis kesulitan menjawab pertanyaan guru PAI. Sementara itu, ada juga peserta didik autis yang prestasi akademik cukup baik, karena peserta didik autis cukup cerdas, sudah bisa menulis dan membaca sehingga anak seperti ini tidak ada kendala dalam prestasi akademik. 4) Ada peserta didik autis yang merasa tertekan karena situasi kelas yang ribut, maka ia melakukan gerakan tubuh yang tidak biasa, seperti memutar-mutarkan tubuhnya.

\section{Faktor Eksternal}

Faktor eksternal adalah faktor di luar siswa, yaitu kondisi lingkungan disekitar siswa (Sukardi, 2013). misalnya dalam lingkungan sekolah meliputi ; guru, teman, dan lingkungan kelas. Dalam suatu interaksi pembelajaran bisa terjadi kurangnya perhatian siswa disebabkan oleh suara guru, mungkin terlalu lemah sehingga suaranya tak bisa ditangkap oleh seluruh siswa, atau pengucapan kalimat yang kurang jelas. Guru yang baik akan terampil mengatur volume suaranya, sehingga pesan akan mudah ditangkap dan diahami oleh seluruh siswa. Guru harus mampu mengatur suara kapan ia harus mengeraskan suaranya, dan kapan harus melemahkan suaranya. Ia juga akan mampu mengatur irama suara sesuai dengan isi pesan yang ingin disampaikan. Melalui intonasi dan pengaturan suara yang baik dapat membuat siswa bergairah dalam belajar, sehingga interaksi pembelajaran tidak membosankan (Sanjaya, 2006).

Menciptakan dan memelihara kondisi belajar yang optimal berhubungan dengan kemampuan guru dalam mengambil inisiatif dalam mengendalikan kegiatan belajar mengajar agar berada dalam kondisi kondusif sehingga perhatian siswa terpusat pada materi pelajaran. Menunjukkan sikap tanggap terhadap berbagai perilaku yang muncul di dalam kelas, baik perilaku yang mendukung seperti tanggap terhadap perhatian siswa, keantusiasan siswa, motivasi belajar siswa yang tinggi, dan lain sebagainya, maupun tanggap terhadap setiap perilaku yang tidak mendukung seperti ketidakacuhan, motivasi belajar yang rendah, dan lain sebagainya. Untuk memberikan kesan tanggap ini bisa dilakukan dengan berbagai cara, di antaranya ; 1) Memberikan komentar baik terhadap materi pelajaran yang akan dipelajari maupun terhadap perilaku siswa. Komentar yang bersifat positif dan bisa menggugah perhatian siswa sangat diperlukan untuk membangun suasana yang optimal. 2) Gerak mendekat, artinya guru perlu memberi perhatian khusus baik kepada individu maupun kepada kelompok. Gerak mendekat akan memberi kesan adanya perhatian guru terhadap aktivitas siswa, sehingga akan terbangun suasana akrab dan bersahabat antara guru dan siswa. Di samping itu, gerak mendekat juga bisa dilakukan untuk mengembalikan kondisi belajar siswa, misalnya gerak mendekat pada siswa yang berperilaku mengganggu (Sanjaya, 2006).

Kendala eksternal (faktor di luar siswa), yaitu guru PAI, antara lain : 1) Guru PAI dalam menyampaikan bahan/materi pelajaran dengan volume suara lemah atau terlalu kecil, sehingga informasi yang disampaikan guru PAI tidak dapat didengar oleh seluruh siswa. 2) Guru PAI dalam pengelolaan kelas belum optimal, suasana kelas yang ribut, sehingga dapat membuat peserta didik autis merasa tertekan. 3) Guru PAI dalam memahami karakteristik anak autis masih terbatas, sehingga guru PAI kurang tanggap terhadap perilaku peserta autis melakukan gerakan tubuh yang tidak biasa, seperti memutar-mutarkan tubuhnya karena ia merasa tertekan. 4) Guru PAI belum mengikuti pelatihan pendidikan dan pengajaran anak berkebutuhan khusus, 
sehingga guru PAI dalam memahami anak berkebutuhan khusus terutama anak autis masih terbatas.

\section{KESIMPULAN}

Interaksi pembelajaran antara guru Pendidikan Agama Islam (PAI) dengan peserta didik autis, dilihat dari komponen-komponen interaksi pembelajaran diketahui ; pada aspek tujuan pembelajaran yang ingin dicapai, guru PAI tidak membedakan tujuan pembelajaran peserta didik autis dengan tujuan pembelajaran peserta didik pada umumnya. Pada aspek bahan/materi pelajaran dan menguasai bahan/materi pelajaran, tidak ada perbedaan dalam pemberian materi pelajaran baik peserta didik autis maupun peserta didik pada umumnya. Pada aspek metode selain menggunakan metode yang relevan, ada juga strategi pembelajaran yang khusus untuk anak autis yaitu guru PAI tidak pernah melakukan kontak mata secara langsung pada peserta didik autis. Pada aspek alat dan sumber belajar, guru PAI menggunakan alat dan sumber belajar yang sama untuk peserta didik autis maupun peserta didik pada umumnya. Dalam hal evaluasi guru PAI memberikan penilaian bersifat individual, di mana peserta didik autis boleh menjawab pertanyaan lebih sedikit dari peserta didik pada umumnya.

Pola komunikasi dalam interaksi pembelajaran antara guru PAI dengan peserta didik autis yaitu komunikasi satu arah (pendidik aktif, peserta didik pasif), sementara pola komunikasi antara guru PAI dengan peserta didik pada umumnya yaitu komunikasi dua arah (pendidik dan peserta didik dapat berperan sama, yakni saling memberi dan menerima aksi). Selain komunikasi verbal, guru PAI juga menggunakan komunikasi nonverbal. Peserta didik autis dalam interaksi pembelajaran adalah ada yang fokus belajar dan ada yang tidak fokus belajar asyik dengan mainannya, ada yang bisa mandiri dalam belajar dan ada yang belum mandiri dalam belajar masih dibantu pendampingnya, ada yang dapat merespon/menjawab guru dan ada juga yang tidak dapat merespon/menjawab guru. Peserta didik autis jarang sekali atau tidak pernah bertanya dengan guru PAI. Peserta didik autis menghindari kontak mata atau melihat dari sudut matanya dengan guru PAI.

Interaksi pembelajaran antara peserta didik pada umumnya dengan peserta didik autis adalah dalam keseharian di sekolah anak autis memerlukan teman atau peserta didik pada umumnya untuk mengembangkan kemampuan melakukan interaksi sosial di sekolah dengan bermain atau belajar bersama. Peran teman atau peserta didik pada umumnya dalam komunitas belajar anak autis dapat difungsikan sebagai media untuk melatih peserta didik autis berkomunikasi. Secara tidak langsung peserta didik pada umumnya juga dapat mengembangkan kemampuan sensori peserta didik autis dan memperbaiki sikap atau perilaku peserta didik autis.

Kendala interaksi pembelajaran terhadap peserta didik autis pada mata pelajaran Pendidikan Agama Islam di Sekolah Dasar Negeri 30 Palembang adalah sebagai berikut ; kendala dalam interaksi pembelajaran dipengaruhi oleh banyak faktor, baik faktor internal maupun faktor eksternal. Kendala dari faktor internal atau faktor dalam peserta didik autis meliputi tingkat kemampuan bicara dan bahasa (komunikasi), tingkat kemampuan interaksi sosial, tingkat kemampuan prestasi akademik, kesehatan dan kestabilan emosi anak. Adapun kendala dari faktor eksternal atau faktor di luar peserta didik autis adalah pada aspek guru PAI. Guru PAI dalam menyampaikan bahan/materi pelajaran volume suaranya lemah atau terlalu kecil, guru PAI juga dalam pengelolaan kelas belum optimal, suasana kelas yang ribut dapat membuat anak autis merasa tertekan, guru PAI dalam memahami karakteristik anak autis masih terbatas, guru PAI belum mengikuti pelatihan pendidikan dan pengajaran anak berkebutuhan khusus. 


\section{DAFTAR PUSTAKA}

Aziz, S. (2015). Pendidikan Seks Anak Berkebutuhan Khusus. Yogyakarta : Gava Media.

Creswell, J.W. (2016). Research Design : Qualitative, Quantitative, and Mised Methods Approaches. trej. Fawaid, A. dan Pancasari, R.K. Yogyakarta : Pustaka Pelajar.

Glazzard, J, et al. (2016). Teaching \& Supporting Children With Special Educational Needs \& Disabilities in Primary Schools, Terj. Suryaman, O. Yogyakarta : Kanisius.

Hayati, N. et. al. (2015). Kemampuan Mengelola Interaksi Edukatif Guru Pendidikan Agama Islam. Jurnal Al-Hikmah vol.12 No.2

Handayani, S. et. al. (2018). Proses Pembelajaran Pendidikan Agama Islam bagi Anak Berkebutuhan Khusus di SDN Perwira Kota Bogor. Journal of Elementary Education vol.2 No.1

Kustawan, D. (2016). Manajemen Pendidikan Inklusif ; Kiat Sukses Mengelola Pendidikan Inklusif di Sekolah Umum dan Kejuruan. Jakarta : Luxima Metro Media.

Koswara, D. (2016). Pendidikan Anak Berkebutuhan Khusus Autis. Jakarta : Luxima Metro Media.

Mukhtar - Iskandar. (2010). Desain Pembelajaran Berbasis Teknologi Informasi Dan Komunikasi. Jakarta : Gaung Persada Press.

Nuryani. et. al. (2016). Pola Komunikasi Guru pada Siswa Anak Berkebutuhan Khusus di Sekolah Menengah Kejuruan Inklusi. Jurnal Kajian Komunikasi vol. 4 No.2

Ramayulis. (2005). Metodologi Pendidikan Agama Islam. Jakarta : Kalam Mulia.

Rohmadi, S.H. (2012). Kurikulum Berbasis Inklusi di Madrasah : Landasan Teori dan Desain Pembelajaran Prespektif Islam. Conference Proceeding Annual Internasional Conference on Islamic Studies. Surabaya 5-8 November.

Rozak, A.R. (2013). Interaksi Pembelajaran Efektif untuk Berprestasi. Jurnal Pilar vol.2 No.2 Sugiyono. (2010). Metode Penelitian Pendidikan : Pendekatan Kuantitatif, Kualitatif, dan $R \& D$. Bandung: Alfabeta.

Sanjaya, W. (2006). Strategi Pembelajaran Berorientasi Standar Proses Pendidikan. Jakarta : Kencana.

Sukardi, I. (2013). Model-Model Pembelajaran Moderen. Palembang : Tunas Gemilang Press. Soekanto, S. (2006). Sosiologi Suatu Pengantar. Jakarta : Rineka Cipta. 